\title{
Employee Injury Cases: Should Courts or Boards Decide Whether Workers' Compensation Laws Apply?
}

In virtually all jurisdictions, workers' compensation laws provide the exclusive remedy for employees injured in the course of employment. ${ }^{1}$ Under these laws the power to grant an initial decision in workers' compensation cases is removed from common law courts and lodged instead in workers' compensation boards. ${ }^{2}$ Compensation boards find facts, apply workers' compensation law to those facts, and calculate employee awards. Ultimately, board decisions are subject to de novo judicial review as to issues of law and "substantial evidence" review as to issues of fact."

These boards differ in several important respects from common law courts. First, findings of fact are made by administrative officers instead of judges and juries; second, the common law defenses of fellow servant, assumption of risk, and contributory negli-

1 See 1 arthur Larson, Workmen's Compensation Law $\$ 1$ (1984 \& Supp. 1985). Workers' compensation laws were enacted in response to rising numbers of employee injuries and deaths in the nineteenth century and dissatisfaction with the common law remedies available to employees. See id. § 5.20; see also National Commission on State Workmen's Compensation Laws, Compendium on Workmen's Compensation 11-18 (1973) [hereinafter cited as Compendium]. But see Rhodes, The Inception of Workmen's Compensation in the United States, 11 ME. L. REv. 35 (1917) (suggesting that workers' compensation laws were motivated by employers' perceptions of excessive tort litigation). When workers' compensation statutes were enacted, empirical data was already available suggesting that there were defects in the common law compensation system. See Crystal Eastman, Work-Accidents AND THE LAW (1910). Before 1910, no more than $15 \%$ of injured employees ever recovered damages under common law causes of action, although $70 \%$ of the injuries were related to working conditions or employers' negligence. CoMPENDIUM, supra, at 11.

2 In this comment, for the sake of consistency, the special forums created by statute to hear workers' compensation claims will be identified as "boards" or "compensation boards," even though their names vary in different states.

3 See, e.g., CAL. LAB. CoDE $\$ 5952$ (West 1971). The "substantial evidence" standard for reviewing facts found by the board has often been developed in the case law without being formally codified. See, e.g., Editorial Am. S.A. v. Kent, 421 So. $2 d 612$ (Fla. Dist. Ct. App. 1982); Hill v. Thompson, 61 N.Y.2d 1018, 463 N.E.2d 1225, 475 N.Y.S.2d 373 (1984). In some states the standard may be even more deferential, though in practice it is likely to be similar. See McKay Plating Co. v. Industrial Comm'n, 91 Ill. 2d 198, 437 N.E.2d 617 (1982) (board's factual determination will not be disturbed unless it is against the manifest weight of the evidence); State ex rel. Griffin v. Industrial Comm'n, 70 Ohio St. 2d 264, 436 N.E.2d 1039 (1982) (per curiam) (court will not disturb board's findings on appeal where there is some evidence to support them). 
gence are eliminated; ${ }^{4}$ third, workers' damages in compensation actions are subject to statutory limits; ${ }^{\varnothing}$ fourth, the rules of evidence and procedure are relaxed; ${ }^{6}$ and fifth, the employee need not show employer negligence to recover. ${ }^{7}$ These changes have led courts and commentators to characterize workers' compensation systems as a compromise between the interests of employer and employee-the employee relinquishes his right to bring a tort action in return for a "certain and speedy" recovery.

1 See 1 A. LARSON, supra note $1, \S 1.10$. The fellow-servant rule, which first appeared in the English case of Priestley v. Fowler, 3 M. \& W. 1, 150 Eng. Rep. 1030 (1837), precluded recovery against an employer when the injury was caused by the negligence of a fellow employee. Under the assumption of risk doctrine, employees were deemed to have assumed the risk of any accidents resulting from hazards normally incident to their employment and therefore were unable to recover against the employer. See W. KEETON, D. DoBBS, R. KEEToN \& D. OWen, Prosser and KEeton ON THe Law of Torts 570-72 (5th ed. 1984). Under contributory negligence, employees who contributed through their negligence to their own accidents and injuries could not recover from the employer even if the employer's negligence was a greater contributing factor to the accident. Id. at 569.

- See 1 A. Larson, supra note $1, \S 1.10$.

- See 3 id. § 77A.10.

7 See 1 id. $\$ 1.10$. All 50 states as well as the District of Columbia have enacted workers' compensation laws that contain similar basic features. See, e.g., CAL. LAB. CoDE $\$ \S 3201-$ 6148 (West 1971 \& Supp. 1986); ILL. ANN. Stat. ch. 48, §§ 138.1-.30 (Smith-Hurd 1969 \& Supp. 1985); N.Y. Work. Comp. Law \$§ 1 to 401 (McKinney 1965 \& Supp. 1986); OHo Rev. Code ANn. $\S \S 4123.01-.99$ (Page 1953 \& Supp. 1984). For a complete list and summary of state workers' compensation laws, see Division of State Workers' Compensation Programs, Office of State Liaison and Legislative Analysis, Employment Standards Administration, U.S. Dep'T of Labor, State Workers' Compensation Laws (1971).

- New York Cent. R.R. v. White, 243 U.S. 188, 201 (1917); see Note, New Policies Bearing on the Negligent Employer's Immunity from Loss-Sharing, $29 \mathrm{ME}$. L. REv. 243, 246-67 (1978); see also Hopkins, Executive Officer Suits Under the Combination Casualty Policy, 25 Fed'N Ins. Couns. Q. 169, 170 (1975) (workers' compensation laws were a compromise, trading acceptance of a fixed measure of relief for waiver of necessity to prove employer negligence); Project, New York Workmen's Compensation Law: Problems and Perspectives, 26 Buffalo L. Rev. 637, 643 (1977) ("Workmen's compensation thus provides partial compensation to all those injured at the expense of those who would be able to recover their entire losses in common law tort actions. This tradeoff is advantageous to workers in general because of a reduction in the expenses of court trials and proceedings.' ") (quoting New York Commission on Employers' Liability, First RePort 19-36 (1911)) (emphasis in original). But ef. Nicholas Ashrord, Crisis in the WorkPlace-Occupational DISEASE AND INJURY 389 (1976) (suggesting that the first American workers' compensation laws were actually an attempt to limit the amount of awards in increasingly successful tort actions by employees during the last quarter of the nineteenth century). See generally Friedman \& Ladinsky, Social Change and the Law of Industrial Accidents, 67 CouUm. L. Rev. 50, 69-72 (1967) (discussing the enactment of workers' compensation statutes). Many commentators view the "compromise" issue in economic terms. See, e.g., 13 Wex Malone, Louisiana Workmen's Compensation Law and Practice § 32 (1951) (employer expected to pass accident costs on to consumers).

Considerable litigation regarding questions of workers' compensation coverage and benefits still occurs, notwithstanding the equitable attractiveness of the "compromise." See Lois MacDonald, Controverted Cases-New York State Workmen's Compensation 13 
But even the most comprehensive workers' compensation systems do not cover all accidents and causes of action that have some connection with the employer-employee relationship. If the accident occurs while the employee is acting outside the "course of employment," a claim for compensation is beyond the jurisdiction of a workers' compensation board. In that instance, traditional tort remedies remain available. Whether an accident is covered by workers'. compensation law or tort law is very important to employers and employees, since that determination controls both the substantive rules of liability and the procedure by which a claim will be resolved.

Although employees have long attempted to avoid workers' compensation systems in order to secure greater recoveries in tort, ${ }^{9}$ these efforts have increased as the disparity between statutory awards and tort awards has widened. This comment addresses a question that arises directly from efforts to avoid the workers' compensation system: should courts or boards resolve the jurisdictional issue of whether tort law or workers' compensation law applies to a particular case? The jurisdictional issue arises whenever an employee files a tort suit in court and the employer's challenge to the court's jurisdiction raises disputed issues of fact. The question of who is to decide what law applies is important because its resolution often determines whether a common law jury or a specialized board will find the facts that ultimately control the juris-

n.13 (1964) (about 5\% to $10 \%$ of New York cases are controverted); Brodie, The Adequacy of Workmen's Compensation as Social Insurance: A Review of Developments and Proposals, 1963 Wrs. L. REv. 57, 63-73 (primary areas of litigation have been existence of employment relationship and causation). See generally Report of the National Commission on State Workmen's Compensation Laws 99-100 (1973) (discussing amount of litigation) [hereinafter cited as National Commission REPORT].

Recent tort law developments favorable to plaintiffs have led some commentators to suggest that the compromise struck by workers' compensation legislation may no longer be valid. See, e.g., Project, supra, at 645-46, 651-52 (suggesting that changes in tort law since the beginning of this century have increased the probability that employees will recover in tort actions, thus disturbing the balance struck by the workers' compensation statutes); see also N. ASHFORD, supra, at 398-422 (criticizing workers' compensation as not providing incentive to reduce hazards).

- Workers' compensation benefits are very meager in comparison to current personal injury awards. See Comment, Johns-Manville Products Corp. v. Superior Court: The NotSo-Exclusive Remedy Rule, 33 Hastings L.J. 263, 268 n.32 (1981) (citing several recent large tort judgments for amounts greatly in excess of actual damages); cf. Hopkins, supra note 8, at 172 ("Although employers had contested the passage by legislatures of the compensation acts because of the projected cost factor, this turned out not (necessarily) to be the case. In actuality, the protection of employers from very large tort suits far outweighed any actual expenses that the employers had to pay in compensation benefits."). 
dictional inquiry. ${ }^{10}$

Part I examines three approaches that courts have adopted for deciding which tribunal has "jurisdiction to determine jurisdiction" in potential workers' compensation actions. The first approach, followed by a majority of jurisdictions that have considered the question, allows the tribunal first hearing the claim to decide the jurisdictional question. The second approach divides the jurisdictional question, giving the court power to determine "fundamental" issues such as whether the defendant is the plaintiff's employer, and giving the board the power to decide whether an injury occurred in the course of employment. The third approach requires that a court defer to the board if there is a "substantial question" as to whether a particular injury occurred in the course of employment. Part II demonstrates the inadequacies of each of these approaches to the problem. Part III draws on the administrative law doctrine of primary jurisdiction to conclude that the jurisdictional question should be decided by the board whenever either party to the action petitions the board to make that determination.

\section{Current Responses to the JuRisdiction Question}

The foundation of every workers' compensation scheme is its coverage provision. Most state statutes provide that workers' compensation laws apply whenever an injury arises out of and occurs in the course of employment. ${ }^{11}$ While some courts have compli-

10 Because the jurisdictional inquiry turns on disputed factual questions, the court's determination will often be made by a jury. See, e.g., Scott v. Industrial Accident Comm'n, 46 Cal. 2d 76, 84, 293 P.2d 18, 23 (1956) (special interrogatory appropriate for jury to determine statutory coverage); Sewell v. Clearing Mach. Corp., 419 Mich. 56, 62, 347 N.W.2d 447, 450 (1984) (judge and jury to determine whether plaintiff is an employee of defendant); O'Rourke v. Long, 41 N.Y.2d 219, 226, 359 N.E.2d 1347, 1353, 391 N.Y.S.2d 553, 559 (1976) (jury may decide plaintiff's status as employee). Common law judges may control the jurisdictional question in some cases, such as where the issue is presented on a motion for directed verdict or a motion to dismiss. See, e.g., Lamar v. Ford Motor Co., 409 S.W.2d 100 (Mo. 1966).

"Forty-two states have adopted the "arising out of and in the course of employment" language. 1 A. LARSON, supra note $1, \S 6.10$. As to the more general "course of employment" concept, 47 states use this phrase. Id. The "arising out of" portion has been thought to refer to causal origin, whereas the "course of employment" language is construed to relate to the time, place, and circumstances of the accident in relation to the employment. Some courts have held that each test must be independently applied and met. See, e.g., Martin v. Unified School Dist. No. 233, 5 Kan. App. 2d 298, 299, 615 P.2d 168, 169-70 (1980). However, Larson urges that the basic concept of compensation coverage is unitary, not dual, and is best expressed in the term "work connection." 1 A. LARSON, supra note 1, § 6.10; cf. Brodie, supra note 8, at 63-64 (determining the existence of the relationship of employment is "one of the most puzzling problems before English and American courts"). 
cated this inquiry by construing the statutory language narrowly ${ }^{12}$ or by creating exceptions to the exclusive nature of workers' compensation laws, ${ }^{13}$ in the vast majority of cases jurisdiction turns on the resolution of two related factual inquiries: (1) whether an employer-employee relationship existed at the time of the injury; and (2) whether the injury occurred in the course of employment. If a court has the power to determine jurisdiction, these factual issues will often be resolved by a jury; if a board has the power to determine jurisdiction, these factual issues will be resolved by administrative officers appointed by the state. ${ }^{14}$

12 Courts have read the "in the course of employment" inquiry narrowly through their use of the so-called "dual capacity" doctrine. See, e.g., Smith v. Metropolitan Sanitary Dist., 77 Ill. 2d 313, 318-19, 396 N.E.2d 524, 527 (1979). Under this doctrine, an employer may be liable in tort for an injury proximately caused by the employer's breach of a duty arising from a legal persona separate and distinct from his status as an employer. 2A A. LARSON, supra note $1, \S 72.81$. Courts typically apply the dual capacity doctrine where the employee is injured in the course of his employment, but the injury is caused by a defective product manufactured by the employer. In such a case, the court may hold that the employee has a tort action against the employer because the employer's liability to users created by the introduction of a product into commerce is separate and distinct from the employer's duty as an employer. See, e.g., Mercer v. Uniroyal Inc., 49 Ohio App. 2d 279, 282, 361 N.E.2d 492, 496 (1976) (hazard must be "common to the public in general"); see also McCormick v. Caterpillar Tractor Co., 85 Ill. 2d 352, 423 N.E.2d 876 (1981); Panagos v. North Detroit Gen. Hosp., 35 Mich. App. 554, 192 N.W.2d 542 (1971).

Until recently, California courts had applied the dual capacity doctrine most extensively. See, e.g., Bell v. Industrial Vangas Inc., 30 Cal. 3d 268, 274-76, 637 P.2d 266, 269-71, 179 Cal. Rptr. 30, 33-35 (1981) (citing cases). The California legislature, however, essentially eliminated the dual capacity doctrine by statutory amendment in 1982. See CAL. LAB. CoDE $\S 3602$ (a) (West Supp. 1986); see also Siva v. General Tire \& Rubber Co., 146 Cal. App. 3d 152, 156 n.6, 194 Cal. Rptr. 51, 53 n.6 (1983).

${ }_{13}$ See, e.g., Blankenship v. Cincinnati Milacron Chems., Inc., 69 Ohio St. 2d 608, 612 13,433 N.E.2d 572, 576 (if an employer acts intentionally, an employee can bring action in tort even though the workers' compensation statute provided that the employer "shall not be liable to respond in damages at common law or by statute for any injury . . received or contracted by an employee in the course of ... employment") (quoting OHio REv. CODE ANN. § 4123.74 (Page 1953 \& Supp. 1984)) (emphasis added), cert. denied, 459 U.S. 857 (1982); Johns-Manville Prods. Corp. v. Superior Court, 27 Cal. 3d 465, 612 P.2d 948, 165 Cal. Rptr. 858 (1980) (employee can maintain suit for injuries caused by fraudulent concealment of disease and its cause) (decision subsequently overruled by legislation, see supra note 11); cf. Mandolidis v. Elkins Indus., Inc., 161 W. Va. 695, 706, 246 S.E.2d 907, 914 (1978) (construing statutory exception for intentional torts to apply to "willful, wanton, and reckless misconduct").

14 Because the factual findings of the board are subject to a very deferential standard of review-the "substantial evidence" standard, see supra note 3-and because the "jurisdictional facts" doctrine has been largely rejected in the workers' compensation context, the boards' decisions as to facts bearing on jurisdiction are essentially final. The jurisdictional fact doctrine held that board findings were not conclusive when they related to the facts on which the jurisdiction of the board depended in the first place. See Crowell v. Benson, 285 U.S. 22, 58-62 (1932); Walker v. United States Gypsum Co., 270 F.2d 857, 859 n.4 (4th Cir. 1959), cert. denied, 363 U.S. 805 (1960); Downham v. Wagner, 408 N.E.2d 606 (Ind. Ct. App. 1980). The rationale for the doctrine was that allowing the board to make conclusive deter- 
In most instances, a plaintiff would prefer to have disputed questions of fact resolved by a jury because jurors are more likely to be sympathetic to an injured worker. Employers, on the other hand, would prefer disputed factual issues to be resolved by specialized administrative officers, who deal with injured plaintiffs on a regular basis and are thus less likely to be swayed by sympathy in a particular case. These intuitions about the behavior of employers and employees are borne out in the cases. An injured employee typically brings a claim in court; just as typically, the employer seeks to dismiss the court action by arguing that the issue of jurisdiction should properly be resolved by the board. ${ }^{\text {is }}$

Faced with these conflicting tendencies of employers and employees, courts have taken a variety of positions on the issue of "jurisdiction to determine jurisdiction." The three dominant responses are presented here.

\section{A. The Majority Approach}

The majority of jurisdictions that have considered the jurisdictional question have ruled that the court and the board have concurrent jurisdiction to determine jurisdiction. ${ }^{16}$ Under the majority approach, the first tribunal to secure jurisdiction over the controversy decides whether workers' compensation laws apply. After that decision is made, jurisdiction becomes exclusive in the tribunal that was found to be appropriate. For example, assume that a factory worker slips on an ice patch and breaks his leg while walking to work on a factory-owned sidewalk. He files a tort action against his employer in a court of general jurisdiction. The court

minations about the facts on which its jurisdiction rested would enable the board to enlarge its statutorily defined power by its own act. See 3 A. Larson, supra note $1, \S 80.41$. The rejection of the doctrine, however, has been based not on a desire to pay greater deference to compensation boards, but on the awareness that any fact-finding by a board-whether it is a finding as to employment relation, timely filing of claim, or injury in the course of employment-bears in some way on its jurisdiction. Most courts have therefore discarded the doctrine and apply substantial evidence review to all fact determinations by boards. Id.

${ }_{15}$ See, e.g., Scott v. Industrial Accident Comm'n, 46 Cal. 2d 76, 293 P.2d 18 (1956); Sewell v. Clearing Mach. Corp., 419 Mich. 56, 347 N.W.2d 447 (1984).

16 The majority approach has been adopted in California, Delaware, Idaho, New Jersey, Oklahoma, and South Dakota. See Yavitch v. Workers' Compensation Appeals Bd., 142 Cal. App. 3d 64, 190 Cal. Rptr. 793 (1983); Ward v. General Motors Corp., 431 A.2d 1277 (Del. Super. Ct. 1981); Anderson v. Gailey, 97 Idaho 813, 555 P.2d 144 (1976); Singer Shop-Rite, Inc. v. Rangel, 174 N.J. Super. 442, 416 A.2d 965 (App. Div. 1980); Jones Drilling Co. v. Woodson, 509 P.2d 116 (Okla. 1973); South Dakota Medical Serv. v. Minnesota Mut. Fire \& Casualty Co., 303 N.W.2d 358 (S.D. 1981); cf. Bjerke v. Heartso, 183 N.W.2d 496 (N.D. 1971) (court is free to decide questions that would normally be referred to the board if the board has lost jurisdiction through lapse of time). 
makes a factual determination that jurisdiction for this suit properly lies with the board, not the court. As soon as this determination is made, the worker's only option is to pursue his claim before the board.

The majority rule was laid down by the California Supreme Court in Scott v. Industrial Accident Commission. ${ }^{17}$ In Scott, the plaintiff was injured while he was an invitee on company premises, and filed an action in state court to recover for his injuries. ${ }^{18}$ The company argued that the court lacked jurisdiction because the board had exclusive jurisdiction over the plaintiff's claim. The company then instructed its workers' compensation insurer to file an application with the board for adjustment of a claim arising from the same injuries that the plaintiff had alleged in the court action. After rejecting the plaintiff's request for a stay of the proceedings, the board began its hearings. ${ }^{19}$ The court then faced the question of whether to stay the board proceedings pending the court's resolution of the jurisdictional issue.

Stating that " $[w]$ hen two or more tribunals in this state have concurrent jurisdiction, the tribunal first assuming jurisdiction retains it to the exclusion of all other tribunals in which the action might have been initiated," the Scott court ordered a stay of the proceedings before the board. ${ }^{20}$ In the court's view, the first tribunal to take jurisdiction may prohibit another tribunal from trying to proceed, even though the second tribunal might already have assumed jurisdiction. ${ }^{21}$

In rendering its judgment, the court made it clear that the sole point of concurrent jurisdiction between the board and the court was "jurisdiction to determine jurisdiction." Thus, only the determination on the matter of coverage would be res judicata in proceedings before another tribunal that involved the same parties or

1746 Cal. 2d 76, 293 P.2d 18 (1956).

${ }^{18} \mathrm{Id}$. at $79,293 \mathrm{P} .2 \mathrm{~d}$ at 20 . The plaintiff was 19 years old, and brought the action through a guardian ad litem.

${ }^{19} I d$. at 79-80, 293 P.2d at 20 . Apparently the plaintiff believed he would be successful in his tort action and, further, that the court would be more likely than the compensation board to find that jurisdiction of his case lay with the court rather than with the board.

${ }^{20} I d$. at 81,293 P.2d at 21.

$2 x$ Prohibition is a legal remedy that affords relief similar to that obtained from an injunction granted by a court of equity against proceedings at law. See Forrest G. FERRIS, The Law of Extraordinary Legal Remedies 312-461 (1926). The writ of prohibition provides an original remedy against encroachment of jurisdiction by restraining subordinate courts and inferior judicial tribunals from exceeding their jurisdiction. Such a writ may issue to an administrative agency acting in a judicial or quasi-judicial capacity. See, e.g., People ex rel. Hurley v. Graber, 405 Ill. 331, 90 N.E.2d 763 (1950); Carpentertown Coal \& Coke Co. v. Laird, $360 \mathrm{~Pa}$. 94, 61 A.2d 426 (1946). 
those privy to them. ${ }^{22}$ The court gave two reasons for limiting concurrent jurisdiction to the issue of jurisdiction: first, such a rule avoids conflicts between boards and courts that might arise if both were free to make contradictory awards relating to the same claims; second, the rule protects litigants from the expense and harassment of multiple litigation. ${ }^{23}$

Under the majority approach, as the Scott court expressly acknowledged, the litigants are placed in a "footrace" to the tribunal of their choice. ${ }^{24}$ An employee is free to file an action in court. Similarly, an employer or insurance carrier may file an application to adjust a claim with the board immediately upon the occurrence of an injury, which may be before or during the furnishing of medical care or compensation payments. ${ }^{25}$ But the party that acts first determines which tribunal will resolve the jurisdictional issue.

\section{B. The "Split-Jurisdiction" Approach}

Whereas the majority approach gives a court power to determine whether a claim is covered by the workers' compensation laws when the court's jurisdiction is invoked prior to that of the board, Michigan case law gives a court the power to decide one aspect of that overall determination but not another. Under Michigan's approach, a court may decide whether a defendant is the plaintiff's employer, but lacks the power to determine whether an injury occurred in the course of employment. ${ }^{26}$

${ }^{22}$ Scott, 46 Cal. $2 \mathrm{~d}$ at 83,293 P.2d at 22 . Although the cases are not entirely clear on this point, the Scott court states what seems the better view-that a determination of the jurisdictional issue on the facts by either a court or a board should bind the other tribunal. See also supra note 14. But cf. O'Rourke v. Long, 41 N.Y.2d 219, 227, 359 N.E.2d 1347, 1354,391 N.Y.S.2d 553, 559 (1976) ("an adjudication by the board that there was a relationship between accident and employment, unless reversed on a direct appeal, would preclude any recovery in a civil action against the employer," but the reverse may not be true).

2346 Cal.2d at 82,293 P.2d at 21.

24 Id. at 89,293 P.2d at 25.

25 Id. at 86, 293 P.2d at 24 .

26 See Sewell v. Clearing Mach. Corp., 419 Mich. 56, 347 N.W.2d 447 (1984). The Michigan approach has not been expressly adopted elsewhere. While some Missouri cases have stressed the board's exclusive jurisdiction over employment-related injuries, see, e.g., Hannah v. Mallinckrodt, Inc., 633 S.W.2d 723, 727 (Mo. 1982) (" "We find no Missouri case holding that the courts have such concurrent jurisdiction but find many to the effect that the Commission has exclusive and original jurisdiction." ") (quoting Sheen v. Dibella, 395 S.W.2d 296, 303 (Mo. Ct. App. 1965)), two other Missouri cases indicate that a court possesses some jurisdiction, thereby suggesting that Missouri is aligned with the split-jurisdiction approach, see Lamar v. Ford Motor Co., 409 S.W.2d 100, 107 (Mo. 1966) (circuit court had jurisdiction to determine whether plaintiff was an employee of the employer); Zahn v. Associated Dry Goods Co., 655 S.W.2d 769, 772 (Mo. Ct. App. 1983) (upholding trial court's discretion to decide that for purposes of determining compensation, employment includes 
In Sewell v. Clearing Machine Corp. ${ }^{27}$ the plaintiff, an employee of Bathey Manufacturing Company, was seriously injured in an industrial accident. After filing a tort action in state court, the plaintiff filed an amended complaint adding Armco Steel Corporation as a defendant. The plaintiff alleged that Armco had assumed control of the safety program at Bathey, and that Armco agents and employees operated the Bathey manufacturing plant for the profit of Armco. In response, Armco contended that it actually was the plaintiff's employer and therefore the plaintiff's exclusive remedy against it was to seek workers' compensation benefits. Armco later asserted further that the board had exclusive jurisdiction to decide the issue of fact concerning the identity of the plaintiff's employer. ${ }^{28}$

The Sewell court conceded that the board had exclusive jurisdiction to decide whether injuries suffered by an employee occurred in the course of employment. Nonetheless, the court found that it retained the power to decide "the more fundamental issue" of whether the plaintiff was an employer or a fellow employee of the defendant. ${ }^{28}$

Under such a split-jurisdiction approach, therefore, courts and boards each have power to decide distinct aspects of the jurisdictional inquiry. Courts may determine employee status-as well as other "fundamental issues"-and boards have exclusive jurisdiction to determine whether the injury occurred in the course of employment.

\section{The "Substantial Question" Approach}

The approach adopted by New York and several other jurisdictions requires a court to defer to the board on the jurisdictional issue if there is a "substantial question" as to whether a particular injury occurred in the course of employment. ${ }^{30}$ Under the substan-

activities reasonably necessary in passing to and from workplace). Thus Missouri law is unsettled in this area.

${ }^{27} 419$ Mich. 56, 347 N.W.2d 447 (1984).

${ }^{28}$ Id. at 58-59, 347 N.W.2d at 448.

${ }^{29}$ Id. at 62,347 N.W.2d at 450 .

so See, e.g., Botwinick v. Ogden, 59 N.Y.2d 909, 453 N.E.2d 520, 466 N.Y.S.2d 291 (1983) (mem.); O'Rourke v. Long, 41 N.Y.2d 219, 359 N.E.2d 1347, 391 N.Y.S.2d 553 (1976). Texas, the District of Columbia, and the federal system (for cases arguably falling under the exclusivity provision of the Federal Employee Compensation Act, 5 U.S.C. $\$ 8116$ (c) (Supp. 1985)) are the other jurisdictions which follow the substantial question approach. See Harrington v. Moss, 407 A.2d 658 (D.C. 1979); Hartford Accident \& Indem. Co. v. Christensen, 223 S.W.2d 45 (Tex. Civ. App. 1949), rev'd on other grounds, 149 Tex. 79, 228 S.W.2d 135 (1950); Hudiburgh v. United States, 626 F.2d 813 (10th Cir. 1980); Reep v. United States, 
tial question approach, jurisdiction to determine jurisdiction rests primarily with the board. Only if there is no "substantial question"-that is, if a court views all factual questions as settled in a given action-can a court make the "pure law" determination of which law applies.

A New York case, O'Rourke v. Long, ${ }^{31}$ provides the clearest statement of this rule. In O'Rourke, the plaintiff, a ten-year-old boy, had been employed illegally as a newspaper delivery boy. After flagging down an ice cream truck and crossing the street to buy ice cream, the plaintiff was struck and injured by a vehicle as he returned to his bicycle. ${ }^{32}$

A few months after the accident, the plaintiff filed a state tort action naming the newspaper as defendant. The trial court dismissed the action. In upholding the dismissal, the New York Court of Appeals held that where the jurisdiction of the board hinged upon the resolution either of purely factual questions or of mixed questions of fact and law, the plaintiff may not choose the courts as the forum for the resolution of such questions. Instead, the responsibility for deciding such "substantial questions" is lodged in the board. ${ }^{33}$

\section{INADEQUACIES OF THE CONTEMPORARY RESPONSES}

Each of the contemporary approaches inadequately resolves the jurisdictional question. To an extent, this stems from the courts' failure to recognize the goal of workers' compensation law: providing a "certain and speedy" mechanism for resolving the claims of injured workers. ${ }^{34}$ The strengths and weaknesses of each approach are set out below.

557 F.2d 204 (9th Cir. 1977); Bailey v. United States, 451 F.2d 963 (5th Cir. 1971); DanielsLumley v. United States, 306 F.2d 769 (D.C. Cir. 1962); Somma v. United States, 283 F.2d 149 (3d Cir. 1960).

3141 N.Y.2d 219, 359 N.E.2d 1347, 391 N.Y.S.2d 553 (1976).

32 Id. at 220,359 N.E.2d at 1349,391 N.Y.S.2d at 555.

ss Id. at 228,353 N.E.2d at 1354, 391 N.Y.S.2d at 560. O'Rourke's distinction between questions of fact and mixed questions of fact and law merely restates the "substantial question" test: under the latter test a court will determine whether there is a "substantial question," which would necessitate an administrative determination; under the O'Rourke test a court will determine whether a particular issue is a "pure law" issue, the determination of which would not require the assistance of another tribunal.

34 See supra notes 4-8 and accompanying text. 


\section{A. The Majority Approach}

The majority approach ${ }^{35}$ is subject to three criticisms: it causes an unnecessary race to the courthouse by litigants; it leads to duplicative litigation; and it creates the possibility of nonuniform results. For these reasons, the majority approach is inconsistent with the goal of providing a "certain and speedy" mechanism for resolving the claims of injured workers.

Because the first party to file has the power to select the decisionmaker on the jurisdictional question, the majority approach leads to a "footrace to filing" between the litigants. Recognizing this, the Scott court argued that alternative approaches posed even greater difficulties: for instance, if jurisdiction were to depend on the first final judgment rather than the first filing, "then we should still have the footrace but it would be a marathon rather than a sprint." 36 This response may be correct, but it fails to explain why there should be any footrace at all. If either tribunal is given the exclusive power to decide the jurisdictional issue, there would be no race.

Not only is the arbitrariness of a footrace difficult to justify, but in practice that footrace has proven to be longer than the hoped-for sprint. As a consequence the majority approach has led to duplicative litigation. Two California cases illustrate this point.

In Busick v. Workmen's Compensation Appeals Board, ${ }^{37}$ the plaintiff, a bookkeeper for a small trucking company, was on vacation to reconsider her decision to leave the company. While on her "vacation," the plaintiff and a co-worker opened up a competing trucking business, acquiring some of her employer's customers. When the plaintiff went to her employer's establishment to pick up her final payroll checks, one of her employers shot her and then killed himself. ${ }^{38}$

The plaintiff first filed a claim with the compensation board, arguing that she had sustained an injury arising out of and in the course of her employment with her former employer. More than six months later, however, the plaintiff commenced a civil action for damages against her former employer's executrix to recover damages for assault and battery. ${ }^{30}$ The state court entered a judg-

${ }^{35}$ See supra notes $16-25$ and accompanying text.

${ }^{38} 46$ Cal. $2 \mathrm{~d}$ at $88-89,293$ P.2d at 25.

${ }^{37} 7$ Cal. 3d 967, 500 P.2d 1386, 104 Cal. Rptr. 42 (1972).

${ }^{38}$ Id. at $970-71,500$ P.2d at 1389,104 Cal. Rptr. at 45.

${ }^{30} \mathrm{Id}$. Plaintiff's inconsistent actions in the two tribunals may have been an attempt to preserve her remedies in both forums against the running of the statute of limitations. A 
ment in the plaintiff's favor for tort damages. In the subsequent workers' compensation proceeding, the board found that the plaintiff's injury did not arise out of and occur in the course of her employment. ${ }^{40}$

Despite the fact that she had secured a large recovery in the civil action, the plaintiff appealed the board's decision. ${ }^{41}$ The reviewing court, however, agreed with the defendant's contention that the state court judgment precluded recovery before the board, since the state court was the first tribunal to reach a final judgment on the plaintiff's claim. ${ }^{42}$ The court rejected the plaintiff's argument that because she filed her claim with the board before she brought her civil action for damages, the state court should have stayed the action on its own motion pending the board's determination of whether the injury was employment-related. The court quoted the Scott court's "first to obtain jurisdiction" test, but pointed out that a party may obtain an order preventing the second tribunal from acting, pending determination by the first tribunal of the jurisdictional question. If both parties fail to do so, the court is free to proceed. ${ }^{43}$ Since the court is not obliged to await the first tribunal's action, the potential for simultaneous litigation in two tribunals remains.

The majority approach also led to duplicative litigation in Sea World Corp. v. Superior Court. ${ }^{44}$ In Sea World, the plaintiff, a secretary, was injured after having "bestridden" a killer whale owned by her employer, an action she took at her supervisor's request. The plaintiff filed actions on the same day with the court and the board. In her application to the board, she stated that her injury arose out of and in the course of her employment by Sea World. In her court complaint, however, she alleged that she was not acting within the scope of her employment when she was injured.

The board obtained jurisdiction over Sea World through ser-

more likely scenario, however, is that after having filed with the compensation board, plaintiff received advice from counsel to pursue the potentially more lucrative award available in a common law court.

${ }^{10} I d$. at 972,500 P.2d at 1390,104 Cal. Rptr. at 46.

11 The plaintiff's desire to pursue her claim heard before the board may have stemmed from the discovery that she had sued a judgment-proof defendant. Although the trial court entered a judgment in favor of the plaintiff for a one-half "joint share" of $\$ 500,000$ general damages and $\$ 150,000$ punitive damages, the court expressly noted that the record did not disclose what part, if any, of this judgment had been satisfied. Id. at $971 \mathrm{n.5}, 500$ P.2d at 1389 n.5, 104 Cal. Rptr. at 45 n.5.

42 Id. at 977,500 P.2d at 1393,104 Cal. Rptr. at 48.

43 Id. at 976, 500 P.2d at 1393,104 Cal. Rptr. at 49.

434 Cal. App. 3d 494, 110 Cal. Rptr. 232 (1973). 
vice of process by mail four days before the court obtained jurisdiction by personal service. Sea World sought a writ of prohibition from an appellate court to restrain further proceedings in the action pending before the original court. Sea World contended that the board had priority to determine the jurisdictional issue because it was the first tribunal to obtain jurisdiction over the parties. ${ }^{45}$

In denying Sea World's request for a writ of prohibition, the court purported to adopt "the rationale and historical perspective of Scott," in addition to looking to "other rules long and widely recognized as governing tribunals whose jurisdiction is generally concurrent." "46 One of those rules, the court said, is that the tribunal where jurisdiction first attached may either insist upon or waive its jurisdiction. ${ }^{47}$ Thus, the board has discretion to refuse to exercise jurisdiction where a court with concurrent jurisdiction has undertaken to exercise jurisdiction over the same subject matter. Furthermore, because this case involved only jurisdiction to determine jurisdiction, as opposed to exclusive subject matter jurisdiction, a litigant may waive, or be estopped from asserting, lack of jurisdiction. ${ }^{48}$ When Sea World moved for summary judgment in the superior court, it waived the board's priority of jurisdiction.

Thus, the Scott court's contention that its approach would lead to a sprint rather than a marathon does not hold true where, as in Busick, a plaintiff decides to pursue remedies in both tribunals without obtaining an order staying the second tribunal's proceedings. In fact, although the Busick court rested its decision on res judicata principles, whereas the Sea World court cited notions of estoppel and the discretionary power of tribunals to waive their priority of jurisdiction, the problems engendered by the two decisions are similar: in both cases there was duplicative litigation, and in both cases the first tribunal to obtain jurisdiction ultimately did not make the controlling determination of whether workers' compensation law was applicable to the plaintiff's injury.

4s Id. at 496-97, 110 Cal. Rptr. at 234. The irony of Sea World's request to the appellate court for a writ of prohibition to restrain proceedings in the original court was that it came only after Sea World's motion for summary judgment on the jurisdictional question had been denied. Thus, the jurisdiction of the original court, which Sea World was now attempting to foreclose through its request to the appellate court for a writ of prohibition, had earlier been specifically invoked by Sea World to make the jurisdictional determination on what was claimed to be a showing of undisputed facts. It was, in short, a classic case of a litigant attempting to get "two bites of the same apple."

48 Id. at 499, 110 Cal. Rptr. at 235.

4 Id.

6 Id. at 501, 110 Cal. Rptr. at 237. 
A more fundamental problem with the majority approach is that it may lead to nonuniform decisions in employee injury cases involving similar facts. The "footrace to file" allows some cases to appear before a court, and others before a board. Since juries are more likely than board officials to be sympathetic to injured plaintiffs in resolving factual issues that are central to the jurisdictional question, similar cases may be held subject to different laws. To illustrate, assume that Worker Jones sustains an injury under the same circumstances as Worker Smith. Jones' lawyer files suit in court immediately following his injury. In a jury trial, the court decides that the injury was not sustained "in the course of employment" and takes jurisdiction to hear the claim. Smith, on the other hand, is a legal novice whose employer quickly files a claim with the board. The board decides that the injury was sustained "in the course of employment" and retains jurisdiction to hear the claim. Thanks to the "footrace," workers' compensation law governs Smith's claim, while state tort law governs Jones' claim.

\section{B. The "Split-Jurisdiction" Approach}

Although the split-jurisdiction approach ${ }^{49}$ leads to uniformity of application, in that similar cases will be decided by the same tribunal, it suffers from an unconvincing rationale and from lack of clarity. The courts' rationale for the split-jurisdiction approach is that the inquiry into the employee's status as an employee is "more fundamental" than the inquiry into "course of employment." Ho However, the courts have given no specific reasons why this is so. As the concurrence in Sewell pointed out, the court's "more fundamental" test seems groundless.

The split-jurisdiction approach can also lead to absurd results. For example, assume that Worker has told Employer that he is going to quit his job in two weeks. On his final scheduled workday, Worker calls in sick but nonetheless stops in at work later that day to pick up his final check. While picking up his check, Worker is injured. Worker brings a tort action against Employer. According to the split-jurisdiction approach, the court can decide whether an

19 See supra notes $26-29$ and accompanying text.

so Sewell, 419 Mich. at 62,347 N.W.2d at 450.

s1 Id. at 65, 347 N.W.2d at 454 (Levin, J., concurring); see also 3 A. LARSoN, supra note $1, \S 80.41$ (the designation of certain facts-like employment relation-as jurisdictional facts is "arbitrary," since the same designation could be applied just as easily to the existence of a compensable accident or to whether the injury occurred in the course of employment). 
employer-employee relationship still existed between Worker and Employer at the time of the injury, although it cannot decide whether the injury occurred in the course of employment.

The problem here is readily apparent: the two questions-employee status and course of employment-are often so intertwined that it is difficult to decide one issue without deciding the other. If the court decides that an employer-employee relationship existed between Worker and Employer at the time of the injury, it seems to follow that the injury occurred in the course of employment. Yet this latter determination, according to the Sewell majority, is supposed to rest exclusively with the board.

Not only is the distinction between these two questions unprincipled, but it has another disturbing implication. What would prevent a court from holding that other aspects of the jurisdictional question are "more fundamental" than the course of employment issue and therefore fall within the realm of its own jurisdiction rather than that of the board? In this manner, courts could wrest particular aspects of the jurisdictional inquiry away from the board.

\section{The "Substantial Question" Approach}

The substantial question approach ${ }^{52}$ has the advantage of requiring a court to defer to the board's expertise on the jurisdictional issue. Yet the courts have neglected to define what constitutes a "substantial question."

Several advantages would accrue to a jurisdiction that adopted this approach in place of the majority approach. First, it promotes uniform decisions because the factual issue of whether an injury occurred in the course of employment is decided by the same factfinder whenever the issue is substantially in dispute. In a jurisdiction following the majority approach, this determination is made by the board in some unpredictable class of cases and by a judge and jury in others. ${ }^{53}$ Second, with power largely vested in a single tribunal, litigants do not need to "race" to file claims, and there is less potential for simultaneous litigation in separate tribunals. ${ }^{54}$ Whenever a plaintiff brings a suit whose facts raise a substantial factual question regarding the applicability of workers' compensation laws, a court must stay its own action pending board

\footnotetext{
62 See supra notes 30-33 and accompanying text.

83 See Bailey v. United States, 451 F.2d 963, 968 (5th Cir. 1971) (Clark, J., dissenting).

s4 See supra notes $36-48$ and accompanying text.
} 
resolution of the jurisdictional issue. ${ }^{.5}$

The main flaw in the substantial question approach is similar to that of the split-jurisdiction approach-ambiguity of terminology. This ambiguity threatens to increase the administrative costs of a workers' compensation system without offering much benefit in return. So long as a court may decide that there is no "substantial question" of workers' compensation coverage in a given case, tort-minded plaintiffs have an incentive to press their common law suits at least to the point where the court decides that there is a substantial question of coverage and that the case must therefore be stayed pending the board's jurisdictional determination. ${ }^{56}$

Further, there is ample evidence to suggest that courts in fact misapply the "substantial question" formula, and thereby increase the incentive for plaintiffs to press costly civil actions. A good example of this problem is provided by the federal case of Bailey $v$. United States. ${ }^{57}$ In Bailey, the plaintiff, a government employee, was injured when her car was struck from behind by a military pickup truck. ${ }^{58}$ Subsequently, the plaintiff and her husband sued in federal court for recovery under the Federal Tort Claims Act (FTCA). ${ }^{59}$ The government argued that the plaintiff's proper remedy was first to seek recovery from the Department of Labor, which has exclusive jurisdiction of compensation for injuries sustained by a government employee "in the performance of [her] duty." "60

The district court held that there was no substantial question as to whether the plaintiff's injury occurred in the performance of her duties. Consequently, suit could be brought under the FTCA. In affirming the district court's decision, the Fifth Circuit appeared to stretch the "substantial question" doctrine in order to keep the

ss See Reep v. United States, 557 F.2d 204, 208 (9th Cir. 1977).

so This incentive is absent under the proposed approach, discussed infra at notes 63-72 and accompanying text, where the mere petition by either party in the pre-trial stage to have the jurisdictional matter decided by the compensation board will automatically have the effect of a stay. Efforts to convince the court that there is no "substantial question" of coverage would become obsolete.

${ }^{87} 451$ F.2d 963 (5th Cir. 1971).

s8 Id. at 965 .

s9 28 U.S.C. \$ 1346 (1982).

so Bailey, 451 F.2d at 964-65. The court quoted from the Federal Employees Compensation Act (FECA), 5 U.S.C. $\$ 8102$ (a) (Supp. 1985). The statute further provides that the liability of the United States "is exclusive and instead of all other liability of the United States . . . to the employee." Id. $\S 8116(c)$. The Secretary of Labor is vested with the power to administer and decide all questions arising under the FECA, and these compensation decisions are final and conclusive and may not be reviewed by a court of law. Id. $\S \S 8128(\mathrm{~b})(1)-(2), 8145$. 
determination of the jurisdictional question for itself-for there was surely some question as to whether the employee was injured in the course of her duties as an employee. ${ }^{61}$ As the dissent pointed out, perhaps the crucial question was not whether a substantial question existed, but whether the court should make the determination of substantiality. ${ }^{62}$

\section{A Proposed Approach}

The conflicting interests of employers and employees in employee injury cases makes necessary a careful determination of which tribunal should decide the jurisdictional issue. Each of the contemporary approaches is inadequate: the majority approach causes a footrace to file that leads to nonuniform decisions and duplicative litigation; the split-jurisdiction approach employs such malleable standards that courts and boards are left in a quandary as to which questions properly lie within their respective jurisdictions; and the "substantial question" approach encourages litigants to gamble on the likelihood of judicial error, thereby increasing the costs of administering a workers' compensation system. The need for a new approach seems clear.

To remedy these deficiencies, this comment proposes that the jurisdictional inquiry be referred to the workers' compensation board upon petition by either party to the action. Since employers can be expected to petition for board determinations whenever there are disputed factual issues relating to jurisdiction, as a practical matter this proposal gives boards the exclusive power to resolve jurisdictional facts-subject of course to substantial evidence review. On an intuitive level this solution is attractive because it takes full advantage of the strengths of both tribunals: courts resolve issues of law (through de novo review) and boards apply their expertise to resolve issues of fact that arise in the employment context.

This proposal avoids the problems of the current approaches. First, it eliminates the race to file. An employee who is injured on

B1 The strongest argument for deciding the jurisdictional issue on the facts-that the employee was a block away from the premises-was not viewed by the court as dispositive. The court rejected the government's argument that the "premises rule" should preclude judicial determination of FECA coverage whenever a federal employee, going to or coming from work, is injured by another federal employee while on government property. Instead, the court deemed the location of the accident to be just one of the factors to be considered in determining whether there is a substantial question of FECA coverage. Bailey, 451 F.2d at 967.

${ }^{62}$ Id. at 968 (Clark, J., dissenting). 
the job does not benefit by filing a tort action before an employer files a claim with the board, since the employer can simply petition to have the board decide which law governs. ${ }^{63}$ Second, judicial resources will not be wasted through duplicative litigation. Given that civil juries are more likely to be sympathetic to injured plaintiffs, employers have a powerful incentive to petition immediately for board determination of the jurisdictional issue if a civil action is filed. Finally, this proposal is cheaper to administer than the "substantial question" approach. Since the new proposal simply turns on a petition by one of the parties, the need for any judicial determination is eliminated. ${ }^{64}$

This proposal finds theoretical support in the administrative law doctrine of primary jurisdiction. ${ }^{65}$ This doctrine is used to determine which tribunal-the court or the administrative agency-should take initial action..$^{6}$ The doctrine allows a court to refer to an agency any issues within their concurrent jurisdiction when doing so will promote uniform decisions or utilize agency expertise.

The rationales behind the primary jurisdiction doctrine support an approach that allows boards to decide the jurisdictional question. ${ }^{6 z}$ Allowing the board to decide the jurisdictional issue

es In order to prevent sandbagging by either party, it would probably be necessary to set a time limit on the ability to petition the board and obtain board determination of the jurisdictional question.

64 Nor will the compensation boards be swamped with cases. Their workloads will undoubtedly increase under this proposal, but the boards will not have to decide the jurisdictional question in all cases. Although strategies of delay will play a part in particular cases, employers typically will have little incentive to petition for board determination unless they think that they have a realistic chance on the facts of convincing the board that workers' compensation laws apply.

is The doctrine of primary jurisdiction originated in Texas \& Pac. Ry. v. Abilene Cotton Oil Co., 204 U.S. 426 (1907), out of a concern for nationally uniform regulation of carrier rates. Id. at 440. The Supreme Court held that the Interstate Commerce Commission had original jurisdiction to entertain proceedings to determine the reasonableness of carrier rates, since without such protection, "power might be exerted by courts and juries generally to determine the reasonableness of an established rate," and "it would follow that unless all courts reached an identical conclusion, a uniform standard of rates in the future would be impossible." Id. See generally 4 Kenneth C. Davis, Administrative Law Treatise §§ 22:1:11 (2d ed. 1983) (discussing primary jurisdiction).

es Kenneth C. Davis, Administrative Law Text $§ 19.01$ (3d ed. 1972).

${ }^{87}$ In the federal context, for example, Harrington v. Moss, 407 A.2d 658 (D.C. 1979), provides support for invoking primary jurisdiction in a case involving the workers' compensation jurisdictional issue. The court stated that

[g]iven the doctrine of primary jurisdiction, courts must defer to administrative agencies for the initial resolution of issues that Congress has placed within the special competence of the agency or that otherwise require the expertise of administrative discretion. In this way, courts can assure uniform application of a statute and deter those 
upon motion of a party advances the interest in uniformity that underlies the primary jurisdiction doctrine. The board would decide practically all cases in which there was doubt about whether to apply tort law or workers' compensation law, since employers would have an incentive to ensure that the board makes the decision in close cases. The workers' compensation laws would therefore be applied uniformly, and the board could apply consistently the two-step inquiry as to employee status and whether an injury occurred in the course of employment. ${ }^{68}$

The agency expertise rationale for primary jurisdiction also supports this proposal. ${ }^{69}$ This rationale recognizes that administra-

who would flout the administrative process (and thus weaken the agency's effectiveness) by encouraging people to ignore its procedures.

Id. at 661 (citations omitted).

${ }^{\text {Bs }}$ Although this proposal might be seen as giving the boards too much control over the jurisdictional inquiry, the inevitable reply is that workers' compensation statutes represent a delicate and complex compensatory scheme which balances the interests of employers and employees. See supra notes 4-8 and accompanying text. The proper route for modifying these laws, given their stated purpose of establishing an exclusive remedy for injured employees against their employers, is within the legislative process. As one state court has argued:

"But where the applicability of the Act is in real dispute and where the evidence . . . is not so overwhelming as to pass from a disputed question of fact to an unalterable legal conclusion, does the circuit court have jurisdiction to make factual findings determinative of the issues even in a suit brought before it originally or should it refuse to accept jurisdiction until the Commission has acted? If in such situations, the circuit court accepts all such cases brought before it and attempts to act with finality when the issue of jurisdiction is raised, is it not assuming concurrent jurisdiction with the Commission and in essence nullifying the legislative intent and enactment which placed exclusive original jurisdiction with the Commission?"

Hannah v. Mallinckrodt, Inc., 633 S.W.2d 723, 727 (Mo. 1982) (quoting Sheen v. Dibella, 395 S.W.2d 296, 303 (Mo. Ct. App. 1965)); see also O'Rourke v. Long, 41 N.Y.2d 219, 228, 359 N.E.2d 1347, 1354, 391 N.Y.S.2d 553, 560 (1976) ("The Legislature has placed the responsibility for these determinations with the Workmen's Compensation Board and there it must remain.").

In 1972, the National Commission on State Workmen's Compensation Laws issued a report that might be used as the basis for legislative modification. The Commission found that workers' compensation plans "in general are inadequate and inequitable." NATIONAL COMMISSION REPORT, supra note 6, at 119. The report listed five objectives of workers' compensation laws: (1) broad coverage of employees and work-related injuries and diseases; (2) substantial protection against interruption of income; (3) provision of sufficient medical care and rehabilitation services; (4) encouragement of safety; and (5) effective delivery of benefits and services. Id. at 117-19. However, the Commission rejected such alternatives as a return to civil damage actions or absorption of workers' compensation by social security, and instead recommended that the essential elements of workers' compensation include increased maximum benefits, virtually universal employee coverage, more coverage for occupational disease, and continuation of payments during disability for life. See id. at 16 (tabulations of recommendations).

68 The agency expertise rationale for primary jurisdiction emerged in Great N. Ry. v. Merchants Elevator Co., 259 U.S. 285, 291 (1922), and United States v. Western Pac. R.R., 
tive agencies may be "better equipped than courts [to decide certain issues because of] specialization [and] insight gained through experience."70 When courts are confronted with problems within an agency's area of expertise, they should take advantage of the special contributions that the agency can make to solving those problems. ${ }^{71}$ Similarly, courts considering employee injury cases should take advantage of the boards' special competence. Compensation boards only hear employee injury cases, and they hear thousands of these cases per year. ${ }^{72}$ Accordingly, they are exposed to a wide variety of both employer-employee relations and employment duties. This exposure allows for more refined factual distinctions in cases where the issues of employee status and course of employment are not readily apparent.

By assuring each party the opportunity for board determination of the jurisdictional question, this proposal cures the problems associated with the current approaches-it advances the goal of uniform decisions, eliminates the possibility of wasteful duplicative litigation, and ensures that courts will take advantage of board strengths.

\section{CONCLUSION}

As damage awards in tort cases continue to rise, victims of work-related accidents will increasingly attempt to recover for their injuries in a common law court rather than through the workers' compensation system. Although these attempts indicate dissatisfaction with the amount of recovery available under workers' compensation laws, it would be a mistake to conclude that they also show dissatisfaction with the basic goal of workers' compensation law-providing a "certain and speedy" recovery for injured workers. The problem of whether boards or courts should decide the jurisdictional question is currently a source of considerable disagreement. This comment's proposal-that boards decide the jurisdictional question upon petition of either party-ensures that

352 U.S. 59, 64 (1956). For a discussion of efficiency grounds as the justification for a separate administrative tribunal for workers' compensation claims, see W. MALONE, M. PLANT, \& J. Little, Cases and Materials on Workers' Compensation and Employment Rights 400 01 (2d ed. 1980); see also Compendum, supra note 1, at 34-35.

${ }^{70}$ Far East Conference v. United States, 342 U.S. 570, 575 (1952).

72 K. Davis, supra note 66, § 19.01 .

72 From 1969 through 1980 there were 500,000 claimants in black lung compensation cases alone. United States Chamber of Commerce, Analysis of Workers' Compensation LAws 1984, at 2 . In 1981, workers' compensation payments in the United States totaled $\$ 15,000,000,000$. Id. at viii. 
workers' compensation laws will continue to provide such a "certain and speedy" system for resolving the claims of injured workers.

Daniel Keating 